\title{
IMPLEMENTASI PENDEKATAN SAINTIFIK PADA PEMBELAJARAN ILMU PENGETAHUAN ALAM DI MIS IKHWANUL MUKMININ
}

\author{
Luthfiyah Zulfaini Silalahi ${ }^{1}$, Alya Putri Dumayanti ${ }^{2}$, Radhiatul Yusra $^{3}$, \\ Nurul Shadrina Husna ${ }^{4}$, Chairunnisa Lubis ${ }^{5}$ \\ 1,2,3,4,5 Mahasiswa Pendidikan Guru Madrasah Ibtidaiyah, Universitas Islam Negeri \\ Sumatera Utara, Indonesia \\ ${ }^{1}$ Email: luthfiyahzsilalahi13032002@gmail.com \\ ${ }^{2}$ Email: alyaapd28@gmail.com \\ ${ }^{3}$ Email: radhiatulyusra2002@gmail.com \\ ${ }^{4}$ Email: nurulhusna76033@gmail.com \\ ${ }^{5}$ Email: cchairunnisalubis@gmail.com
}

\begin{abstract}
ABSTRAK
Implementasi pendekatan saintifik merupakan sesuatu yang perlu dikaji lebih mendalam demi menciptakan proses pembelajaran yang aktif dan efisien. Penelitian ini bertujuan untuk mengetahui rencana pelaksanaan pembelajaran dan penerapan pendekatan saintifik yang dilakukan guru IPA. Adapun metode yang digunakan dalam penelitian ini yakni metode penelitian kualitatif yang juga disebut sebagai penelitian naturalistik. Hasil dalam penelitian ini adalah bahwa Guru IPA memahami tentang pelaksanaan pendekatan saintifik secara teoritis, dan dilengkapi dengan perencanaan dalam dokumen RPP yang dipersiapkan sebelum pembelajaran dilangsungkan. Pada proses penerapan pendekatan saintifik, dibutuhkan waktu yang lebih lama untuk pelaksanaan indikator mengamati, dimana media yang ditampilkan terbatas pada penggunaan kertas sederhana, disebabkan terbatasnya media pembelajaran pendukung seperti LCD Proyektor, dan lain sebagainya.
\end{abstract}

Kata Kunci: Pendekatan Saintifik, Indikator Pendekatan Saintifik, Mata Pelajaran IPA.

\begin{abstract}
The implementation of a scientific approach is something that needs to be studied more deeply in order to create an active and efficient learning process. This study aims to determine the implementation of learning plans and the application of the scientific approach by science teachers. The method used in this research is a qualitative research method which is also known as naturalistic research. The result of this study is that the science teacher understands the theoretical scientific approach, and is equipped with a plan in the RPP document which is prepared before the lesson takes place. In the process of applying the scientific approach, it takes a longer time to carry out observations, where the media displayed is limited to the use of simple paper, due to the limited supporting learning media such as LCD projectors, and so on.
\end{abstract}

Keywords: Scientific Approach, Scientific Approach Indicators, Science Subjects.

\section{PENDAHULUAN}

Pendidikan adalah usaha sadar dan terencana dalam upaya mengembangkan minat dan bakat peserta didik. Pendidikan diharapkan mampu menciptakan manusia yang baik dan 
berkualitas. Dengan demikian, maka muncullah berbagai upaya untuk menggapai itu, hingga lahirnya metode pembelajaran Saintifik, yang mulai digalakkan sejak kurikulum 2013 diperkenalkan.

Permendikbud Nomor 103 Tahun 2014 memberikan penjelasan bahwa pendekatan saintifik dioperasionalisasikan dalam bentuk kegiatan pembelajaran yang pada kegiatannya memuat aktivitas mengamati, menanya, mengumpulkan informasi (mencoba), menalar (mengasosiasi), dan mengomunikasikan. Masing-masing aktivitas ini tergolong sebagai aktivitas layaknya seorang ilmuan, yang melewati beragam tahapan. Saintifik juga merupakan pembelajaran yang berorientasi pada peserta didik. Dengan demikian, Guru dalam hal ini bertugas sebagai fasilitator dalam kelas.

Untuk mendapatkan kelima pengalaman tersebut, Permendikbud Nomor 22 Tahun 2016, merekomendasikan agar diterapkan pembelajaran berbasis penyingkapan/ penelitian (Discovery/ Inquiry Learning), pembelajaran berbasis pemecahan masalah (Problem Based Learning), dan pembelajaran berbasis proyek (Project Based Learning).

Pembelajaran dengan pendekatan saintifik adalah proses pembelajaran yang dirancang sedemikian rupa agar peserta didik secara aktif membangun konsep, hukum atau prinsip melalui tahapan-tahapan mengamati (untuk mengidentifikasi atau menemukan masalah), merumuskan masalah, mengajukan atau merumuskan hipotesis, mengumpulkan data dengan berbagai teknik, menganalisis data, menarik kesimpulan dan mengomunikasikan konsep, hukum, atau prinsip yang ditemukan.

Siswa sebagai subjek dalam pendidikan, dituntut agar dapat aktif dalam belajar mencari informasi dan mengeksplorasi sendiri atau secara berkelompok. Guru hanya berperan sebagai fasilitator dan pembimbing ke arah pengoptimalan pencapaian ilmu pengetahuan yang dipelajari. Diharapkan dalam proses pembelajaran siswa mau dan mampu mengemukakan pendapat sesuai dengan apa yang telah dipahami, berinteraksi secara positif antara siswa dengan siswa maupun antara siswa dan guru apabila ada kesulitan.

Sesuai dengan tujuan pendidikan nasional dan untuk mengikuti perkembangan Ilmu Pengetahuan dan Teknologi (IPTEK) yang maju sangat pesat, maka sains memiliki peranan yang dinilai cukup penting, yakni IPA merupakan salah satu ilmu dasar yang kegunaannya tidak dapat dipisahkan dari ilmu pengetahuan dan teknologi, karena hubungannya sangat erat.

Pengajaran IPA di sekolah bertujuan agar siswa dapat memperoleh kemampuan berpikir logis, kritis dan sistematis. Melalui pengajaran sains, siswa mampu 
mengembangkan kemampuan untuk berpikir secara logis dan memiliki keterampilan berpikir kritis dalam kehidupan sehari-hari.

Tujuan diterapkannya pendekatan saintifik adalah untuk mencapai tujuan pembelajaran secara efektif efisien dan harapannya dapat ditempuh dengan singkat. Bagi siswa dengan minat belajar rendah, akan merasa sesuai dikarenakan mereka akan merasa bahwa cara gurunya mengajar dapat membuatnya menjadi paham lebih cepat dan mudah. Itu tantangan terbesar bagi setiap guru, mencerdaskan peserta didik dengan kemampuan di bawah peserta didik yang pandai (MA Insan Generasi Islami. Online. 2019).

Menurut Permendikbud Nomor 81 A Tahun 2013 lampiran IV, proses pembelajaran dalam pendekatan Saintifik terdiri atas lima hal pokok yang kerap disebut sebagai 5M, yakni:

1. Mengamati;

2. Menanya;

3. Mengumpulkan informasi/ eksperimen;

4. Mengasosiasikan/ mengolah informasi;

5. dan mengkomunikasikan.

Adapun deskripsi langkah pembelajaran dalam pendekatan siantifik, dapat terlihat pada tabel berikut ini.

Tabel. Deskripsi Langkah Pembelajaran Dalam Pendekatan Saintifik (Lampiran Permendikbud No. 103 Tahun 2014)

\begin{tabular}{|c|c|c|}
\hline $\begin{array}{c}\text { LANGKAH } \\
\text { PEMBELAJARAN }\end{array}$ & DESKRIPSI KEGIATAN & $\begin{array}{l}\text { BENTUK HASIL } \\
\text { BELAJAR }\end{array}$ \\
\hline Mengamati & $\begin{array}{l}\text { Mengamati dengan indra } \\
\text { (membaca, mendengar, } \\
\text { menyimak, melihat, menonton, } \\
\text { dan sebagainya) dengan atau } \\
\text { tanpa alat. }\end{array}$ & $\begin{array}{l}\text { Perhatian pada waktu } \\
\text { mengamati suatu objek/ } \\
\text { membaca suatu tulisan/ } \\
\text { mendengar suatu penjelasan, } \\
\text { catatan yang dibuat tentang } \\
\text { yang diamati, kesabaran, } \\
\text { waktu (on task) yang } \\
\text { digunakan untuk mengamati }\end{array}$ \\
\hline Menanya & $\begin{array}{l}\text { Membuat dan mengajukan } \\
\text { pertanyaan, tanya jawab, } \\
\text { berdiskusi tentang informasi } \\
\text { yang belum dipahami, } \\
\text { informasi tambahan yang ingin } \\
\text { diketahui, atau sebagai } \\
\text { klarifikasi. }\end{array}$ & $\begin{array}{l}\text { Jenis, kualitas, dan jumlah } \\
\text { pertanyaan yang diajukan } \\
\text { peserta didik (pertanyaan } \\
\text { faktual, konseptual, } \\
\text { prosedural, dan hipotetik) }\end{array}$ \\
\hline $\begin{array}{l}\text { Mengumpulkan } \\
\text { Informasi }\end{array}$ & $\begin{array}{l}\text { Mengeksplorasi, mencoba, } \\
\text { berdiskusi, mendemonstrasikan, } \\
\text { meniru bentuk/ gerak, } \\
\text { melakukan eksperimen, }\end{array}$ & $\begin{array}{l}\text { Jumlah dan kualitas sumber } \\
\text { yang dikaji/ digunakan, } \\
\text { kelengkapan informasi, } \\
\text { validitas informasi yang }\end{array}$ \\
\hline
\end{tabular}


Menalar/

Mengasosiasikan
Mengkomunikasikan membaca sumber lain, buku teks, mengumpulkan data dari nara sumber melalui angket, wawancara, dan emodifikasi/ menambahi/ mengembangkan Mengolah informasi yang sudah dikumpulkan, menganalisis data dalam bentuk membuat kategori, mengasosiasi atau menghubungkan fenomena/informasi yang terkait dalam rangka menemukan suatu pola dan menyimpulkan. dikumpulkan, dan instrumen/ alat yang digunakan untuk mengumpulkan data.

Mengembangkan interpretasi, argumentasi dan kesimpulan mengenai keterkaitan informasi dari dua fakta/ konsep, interpretasi argumentasi dan kesimpulan mengenai keterkaitan lebih dari dua fakta/ konsep/ teori, menyintesis dan argumentasi serta kesimpulan keterkaitan antarberbagai jenis fakta/ konsep/ teori/ pendapat; mengembangkan interpretasi, struktur baru, argumentasi, dan kesimpulan yang menunjukkan hubungan fakta/ konsep/ teori dari dua sumber atau lebih yang tidak bertentangan;

Mengembangkan
interpretasi, struktur baru,
argumentasi, dan
kesimpulan dari konsep/
teori/ pendapat yang berbeda
dari berbagai jenis sumber
Menyajikan hasil kajian
(dari mengamati sampai
menalar) dalam bentuk
tulisan, grafis, media
elektronik, multimedia dan
lain-lain

Hasil observasi yang dilakukan, membuat kesimpulan bahwa Guru IPA di MIS Ikhwanul Mukminin belum sepenuhnya menerapkan pendekatan saintifik. Hal ini dapat terlihat dari kesediaan waktu untuk bertanya kepada peserta untuk bertanya yang tidak dilakukan saat pembelajaran berlangsung. Selain itu, hasil observasi juga menggambarkan bahwa pembelajaran terkesan membosankan, dan belum sepenuhnya aktif. 


\section{METODE PENELITIAN}

Metode penelitian dalam hal ini menggunakan jenis Penelitian Kualitatif, dimana ini juga dikenal sebagai penelitian naturalistic, yang menggunakan lingkungan alamiah dan tidak dimanipulasi atau diatur sedemikian rupa (Hasyim, A. 2016).

Adapun sifat dari penelitian kualitatif itu sendiri yakni menuturkan pemecahan masalah yang ada di lokasi penelitian berdasarkan data-data temuan, menganalisis, dan menginterpretasikannnya (Nasbuko, 2015). Selanjutnya, yang menjadi tujuan dalam penelitian kualitatif adalah membuat pecandraan secara sistematis, akurat mengenai faktafakta yang terjadi atau ditemui dilapangan (Suryabrata, S. 2013).

Peneliti terlebih dahulu datang ke lokasi penelitian untuk mengambil data berdasarkan observasi lapangan yang dilakukan di MIS Ikhwanul Mukminin. Berdasarkan berbagai hasil observasi yang dilakukan, peneliti merumuskan dan mengelompokkan bagian tertentu untuk yang berkaitan langsung dengan fokus penelitian.

Peneliti juga mengambil data melalui wawancara, dengan membagi kepada informan primer dan informan sekunder. Informan Primer adalah Guru IPA yang mengajar di MIS Ikhwanul Mukminin. Sedangkan yang menjadi Informan Sekunder, adalah Kepala Sekolah, Guru (teman sejawad) yang ada di MIS Ikhwanul Mukminin.

Peneliti juga melakukan studi dokumen dengan mengambil data dari berbagai pihak yang terkait langsung dalam penelitian, sebagai upaya penguatan terhadap permasalahan yang diteliti. Peneliti mengambil data dari tenaga tata usaha, sebagai tempat dokumen berada, dan tidak menutup kemungkinan untuk menggunakan data dari pihak terkait lainnya yang relefan.

\section{HASIL DAN PEMBAHASAN}

\section{A. Persiapan dan Pemahaman Guru IPA Terhadap Pendekatan Saintifik}

Pemahaman tentang sebuah istilah atau pendekatan tertentu adalah hal yang mutlak diketahui bagi praktisi pendidikan atau guru. Dalam hal ini, Guru IPA diharapkan memahami tentang pendekatan saintifik yang dilangsungkan. Hasil wawancara dengan Guru IPA, mengemukakan bahwa pemahaman tentang pendekatan saintifik dipandang cukup. Guru IPA mengetahui berbagai indikator yang ada pada pendekatan saintifik.

Hal ini juga diperjelas dari hasil wawancara dengan Kepala Sekolah, yang mengungkapkan bahwa guru yang ada di sekolah juga pernah diberikan keilmuan umum tentang Pendekatan Saintifik. Kepala Sekolah juga menjelaskan bahwa guru IPA sudah memiliki pengetahuan dasar yang cukup tentang praktik saintifik dalam pembelajaran. 
Rencana Pelaksanaan Pembelajaran (RPP) merupakan bagian yang wajib dipersiapkan oleh Guru sebelum melakukan aktivitas belajar mengajar. Dalam hasil wawancara yang peneliti lakukan terhadap Kepala Sekolah, menjelaskan bahwa Guru IPA membuat RPP dengan tepat waktu, dan diserahkan kepada Kepala Sekolah saat waktu yang ditentukan.

Hal ini juga sejalan dengan hasil dokumen yang ditemukan, bahwa ditemukannya dokumen berupa Rencana Pelaksanaan Pembelajaran (RPP) yang dibuat oleh guru IPA, yang disana juga menguraikan tentang langkah-langkah praktik pembelajaran dengan melibatkan indikator pendekatan saintifik.

\section{B. Penerapan Pendekatan Saintifik}

Penerapan pendekatan saintifik semestinya mengacu pada indikator dari pendekatan saintifik yang dimaksudkan dalam Permendikbud Nomor 81 A Tahun 2013 lampiran IV, yang menjabarkan tentang proses pelaksanaan pendekatan saintifik.

Hasil wawancara dengan guru IPA, mengemukakan bahwa Guru IPA mengetahui tentang berbagai indikator yang ada dalam pendekatan saintifik. Guru IPA juga menuturkan tentang pemahaman $5 \mathrm{M}$, yakni mengamati, menanya, mengmengumpulkan informasi, mengasosiasi dan mengkomunikasikan.

\section{Aktivitas Mengamati}

Mengamati adalah memberikan kesempatan kepada peserta didik dengan melihat media pembelajaran yang ditampilkan oleh guru terkait tentang materi ajar yang dilangsungkan. Dalam hal ini, guru dijadikan sebagai fasilitator.

Hasil wawancara dengan Guru IPA menerangkan bahwa pemahaman seputar aktivitas mengamati sudah cukup untuk dimengerti. Dalam praktiknya, peserta didik juga diberikan waktu berkisar 15-20 menit untuk mengamati media yang disajikan.

Lebih lanjut, Guru IPA juga menuturkan bahwa 15-20 menit adalah waktu yang tergolong panjang untuk menghabiskan waktu dalam penyajian materi. Bila itu menggunakan video, justru akan jauh lebih membutuhkan waktu yang tidak terlalu lama.

Hal ini diperkuat dari hasil wawancara dengan Kepala Sekolah sebagai Informan, yang memberikan penjelasan bahwa guru pada dasarnya tidak memiliki kendala yang berarti dalam penerapan pendekatan saintifik di kelas. Namun, ketersediaan media pembelajaran yang ada di sekolah untuk mendukung itu masih minim. Kepala Sekolah juga melanjutkan bahwa hal yang umum dipraktikkan adalah menggunakan media seperti LCD Proyektor, Speaker pendukung, dan lain sebagainya masih belum tersedia secara lengkap.

Hal ini juga diperkuat dengan ditemukannya dokumen sarana di MIS Ikhwanul Mukminin, yang memberikan gambaran bahwa LCD Proyektor yang tersedia dengan jumlah 
2 unit. Keadaan ini memperkuat bahwa media pendukung belum tersedia sepenuhnya untuk aktivitas saintifik di kelas.

Guru bidang studi IPS (teman sejawad), juga menuturkan melalui hasil wawancara bahwa guru IPA terlihat menyiapkan media pembelajaran dengan kertas, yang akan digunakan untuk penyajian materi ajar. Namun, itu tidak setiap hari terlihat.

Dari hasil observasi, wawancara dan studi dokumen di atas, maka dapat diambil kesimpulan bahwa guru IPA membutuhkan waktu yang lebih lama dalam menerapkan indikator mengamati dalam pendekatan saintifik.

\section{Aktivitas Menanya}

Aktivitas menanya dalam pendekatan saintifik berbentuk kegiatan bertanya yang dilakukan peserta didik kepada guru saat penyajian materi. Langkah ini, merupakan langkah kedua setelah mengamati media yang ditampilkan oleh guru.

Guru IPA menuturkan bahwa dalam penerapan pendekatan saintifik, ia memberikan waktu kepada para peserta didik untuk menanyakan sesuatu tentang apa yang terjadi, dan kaitan antara materi pelajaran dengan media yang ditampilkan. Namun hal yang umum terjadi adalah bahwa butir pertanyaan yang dilontarkan dari peserta didik terkadang belum sesuai dengan apa yang diharapkan, atau apa yang dipelajari.

Melalui hasil observasi yang dilakukan, bahwa guru IPA belum sepenuhnya memberikan deskripsi atau penjelasan tentang indikator dari pendekatan saintifik kepada para peserta didik. Hal ini menyebabkan peserta didik tidak sepenuhnya siap untuk mengikuti pembelajaran. Keadaan ini memungkinkan untuk terciptanya pertanyaan yang tidak masuk akal, atau pertanyaan diluar dari topik pembahasan, yang disebabkan dari pengabaian dari konsep bertanya dalam praktik pendekatan saintifik.

Hasil wawancara dengan Guru IPA juga memberikan penjelasan bahwasanya memberikan penjelasan tentang poin bertanya dalam pendekatan saintifik, belum sepenuhnya diterapkan. Meski indikator pendekatan saintifik itu diterapkan secara keseluruhan, diperlukan untuk penjelasan dari masing-masing indikator, agar para peserta didik memahami akan tindakan yang semestinya dilakukannya.

\section{E. Aktivitas Mengumpulkan Informasi}

Mengumpulakan informasi dalam pendekatan siantifik diartikan sebagai menyusun dan mengelompokkan atas objek atau kejadian tertentu. Dari aktivitas ini, akan menghasilkan klasifikasi yang berguna untuk melatih peserta didik dalam menunjukkan persamaan, perbedaan, hubungan timbal balik, dan lain sebagainya. 
Hasil observasi yang dilakukan, menunjukkan bahwa guru IPA telah menerapkan indikator mengumpulkan informasi. Guru memberikan waktu kepada peserta didik untuk menyusun hal yang telah dilewati peserta didik, terkait tentang materi yang diajarkannya. Hal ini sejalan dengan hasil wawancara yang dilakukan kepada Guru IPA, yang memberikan penjelasan bahwa mengumpulkan informasi dilakukan dengan cara memberikan kesempatan kepada peserta didik, untuk menuangkan hal yang serupa dengan materi pelajaran, yang sebelumnya telah mereka alami dalam aktivitas sehari-hari baik di rumah, lingkungan bebas, atau dalam hal lainnya.

\section{F. Aktivitas Mengasosiasi}

Mengasosiasi juga kerap disebut sebagai menyimpulkan, dan juga dikenal sebagai inferensi. Hal ini berbentuk sebuah pernyataan yang dibuat berdasarkan fakta dari hasil pengamatan. Hasil inferensi umumnya dikemukakan sebagai pendapat seseorang atas apa yang telah diamati.

Hasil observasi mengemukakan bahwa guru IPA memberikan kesempatan kepada para peserta didik untuk mengasosiasi. Hal ini diperjelas dalam hasil wawancara yang dilakukan terhadap Guru IPA, yang menerangkan bahwa mengasosiasi adalah langkah yang dilewati dalam pembelajaran menggunakan saintifik. Pada praktiknya, langkah ini membutuhkan waktu yang tidak sebentar. Tercatat hingga 10-15 menit waktu yang dihabiskan untuk bagian ini.

Hasil pengamatan yang dilakukan, peneliti menemukan bahwa langkah mengasosiasikan dilakukan secara individu atau masing-masing peserta didik, meski membentuk kelompok adalah hal yang diharapkan dalam penerapan pendekatan saintifik.

Keadaan ini dibenarkan dari hasil wawancara yang dilakukan terhadap Guru IPA, yang memberikan penjelasan bahwa peserta didik dibelajarkan dengan tanpa membentuk kelompok. Meski hal ini tidak sepenuhnya terjadi pada setiap pertemuan, pada dasarnya membentuk kelompok adalah sesuatu yang menjadi pemicu keributan dalam kelas yang ada.

\section{G. Aktivitas Mengkomunikasikan}

Mengkomunikasikan merupakan langkah terakhir dalam penerapan pendekatan saintifik. Mengkomunikasikan maksudnya adalah aktivitas menyampaikan pendapat hasil keterampilan proses. Hal ini dapat berupa penyampaian melalui lisan maupun tulisan.

Melalui hasil observasi yang dilakukan di lapangan, memberikan penjelasan bahwasanya Guru IPA melewati tahapan mengkomunikasikan saat penggunaan pendekatan saintifik dalam pembelajaran di kelas. Dalam pengamatan yang dilakukan, peserta didik menyusun dan mengkomunikasikan dengan menggunakan bentuk tulisan. 
Melalui wawancara yang dilakukan terhadap Guru IPA, memberikan penjelasan bahwa bagian mengkomunikasikan adalah bagian yang kerap sekali tertinggal, meski tidak setiap saat. Mengkomunikasikan kerap sekali menjadi bagian yang sering terlewatkan. Hal ini terjadi disebabkan peserta didik yang tidak sepenuhnya siap untuk mengkomunikasikan dari apa yang ditugaskan kepada mereka.

Hal ini juga diperkuat dengan studi dokumen yang peneliti lakukan, yang memperlihatkan bahwa lembar kerja siswa yang terkumpul atau dikumpulkan oleh guru. Masing-masing peserta didik dalam pembelajaran menyelesaikan tugas yang diberikan.

Dari pengamatan dan wawancara yang dilakukan, dapat diketahui bahwa guru IPA menggunakan langkah ini dan berjalan dengan baik. Pada praktiknya, bagian ini membutuhkan waktu yang lebih lama untuk kesiapan peserta didik dalam menyampaikan hasil dari tugas yang diberikan. Oleh karenanya, hal ini menjadi sesuatu yang kerap sekali disajikan dalam bentuk tulisan, dan belum sering digunakan dalam bentuk lisan.

\section{SIMPULAN}

Pembelajaran dengan pendekatan saintifik adalah proses pembelajaran yang dirancang sedemikian rupa agar peserta didik secara aktif membangun konsep, hukum atau prinsip melalui tahapan-tahapan mengamati (untuk mengidentifikasi atau menemukan masalah), merumuskan masalah, mengajukan atau merumuskan hipotesis/ pertanyaan, mengumpulkan data dengan berbagai teknik (mengumpulkan informasi), menganalisis data, menarik kesimpulan dan mengomunikasikan konsep, hukum, atau prinsip yang ditemukan. Tujuan diterapkannya pendekatan saintifik adalah untuk mencapai tujuan pembelajaran secara efektif efisien dan harapannya dapat ditempuh dengan singkat.

Perencanaan dan pemahaman guru IPA terhadap pendekatan saintifik tergolong cukup. Hal ini terlihat dari hasil dokumen yang ditemukan berupa Rencana Pelaksanaan Pembelajaran (RPP) yang tersedia dan dibuat dengan menjelaskan paparan kegiatan dalam pembelajaran.

Guru IPA telah menerapkan masing-masing indikator dalam pendekatan siantifik. Pada praktiknya, bagian yang kerap sekali menjadi penghalang adalah persoalan waktu yang lebih banyak dihabiskan dikarenakan faktor media pembelajaran yang belum mencukupi. Disamping itu, hal lain yang berpengaruh adalah indikator menyimpulkan, dimana lebih banyak menghabiskan waktu untuk peserta didik dalam menyusun laporan dari hasil pengamatan yang dilakukan. 


\section{SARAN}

Adapun yang menjadi saran dalam penelitian ini yakni bagi peneliti selanjutnya, bahwa hasil penelitian ini dapat dijadikan sebagai bahan pertimbangan dan referensi untuk penelitian lanjutan, dan dalam upaya memperdalam pendekatan saintifik.

\section{DAFTAR PUSTAKA}

Abdullah, AN, \& Wangge, YS (2021). Peningkatan Motivasi dan Aktivitas belajar IPA Melalui Pendekatan Saintifik pada siswa kelas IV SDN Ende 1. Cetta: Jurnal Ilmu ..., jayapanguspress.penerbit.org, http://jayapanguspress.penerbit.org/index.php/cetta/article/view/1279

Abdurrohman, A, \& Jaelani, A (2019). IMPLEMENTASI PEMBELAJARAN TEMATIK INTEGRATIF TEMA “AKU DAN KESEHATANKU” MELALUI PENDEKATAN SAINTIFIK. PROSIDING _.., jurnal.univpgri-palembang.ac.id, https://jurnal.univpgri-palembang.ac.id/index.php/Prosidingpps/article/view/2916

AFRIYANI, L (2021). IMPLEMENTASI PEMBELAJARAN IPA MENGGUNAKAN PENDEKATAN SAINTIFIK DI SMP ALAM AL AQWIYA CILONGOK., erepository.perpus.iainsalatiga.ac repository.perpus.iainsalatiga.ac.id/10656/

http://e-

Ahmadi dan Cholid. 2015. Metodologi Penelitian, Jakarta: Bumi Aksara

Andriyani, M, Harahap, F, \& Silaban, R (2018). Meningkatkan Aktivitas dan Hasil Belajar Siswa pada Pembelajaran IPA Menggunakan Pendekatan Saintifik Siswa Kelas V SD Sabilina Tembung. Jurnal Tematik, jurnal.unimed.ac.id, https://jurnal.unimed.ac.id/2012/index.php/tematik/article/view/12629

ASTRIANA, D (2020). ... PENDEKATAN SAINTIFIK BERBASIS MULTIMEDIA INTERAKTIF TERHADAP MINAT DAN HASIL BELAJAR SISWA PADA MATA PELAJARAN ILMU PENGETAHUAN ...., repo.iain-tulungagung.ac.id, http://repo.iain-tulungagung.ac.id/id/eprint/15782

Aulia, J, Zarkasih, Z, \& Nova, TL (2020). Meta-Analisis Pengaruh Penerapan Pendekatan Saintifik Berbantuan Komik terhadap Hasil Belajar IPA Siswa SMP. Journal of Natural $\quad$..., ejournal.uin-suska.ac.id, http://ejournal.uinsuska.ac.id/index.php/JNSI/article/view/9617

Dini, J. P. A. U. (2021). Pengembangan Model Pembelajaran Saintifik Berbasis Kearifan Lokal untuk Perkembangan Kognitif Anak Usia 5-6 Tahun. Jurnal Obsesi: Jurnal Pendidikan Anak Usia 1557-1565, https://doi.org/10.31004/obsesi.v5i2.898

Faqih, N (2019). Peningkatan Aktivitas dan Hasil Belajar Siswa pada Pembelajaran IPA Materi Gerak Benda Melalui Pendekatan Saintifik. Trapsila: Jurnal Pendidikan Dasar, journal.uwks.ac.id, https://journal.uwks.ac.id/index.php/trapsila/article/view/720

Hasbullah, TPG, Shalahudin, S, \& Siregar, N (2018). IMPLEMENTASI PENDEKATAN SAINTIFIK UNTUK MENINGKATKAN KEAKTIFAN BELAJAR ILMU PENGETAHUAN ALAM (IPA) PADA SISWA KELAS IV ..., repository.uinjambi.ac.id, http://repository.uinjambi.ac.id/id/eprint/216 
Hasnunidah, N, Rosidin, U, \& ... (2018). Pendekatan Saintifik dan Permasalahan Pembelajarannya Pada Mata Pelajaran Ipa Smp Di Kota Bandar Lampung. Prosiding Seminar jurnalfkip.unram.ac.id, http://jurnalfkip.unram.ac.id/index.php/SemnasBIO/article/view/681

Hasyim, A. 2016. Metode Penelitian Dan Pengembangan di Sekolah. Yogyakarta: Media Akademi

Haqiqi, AK (2019). Telaah Implementasi Kurikulum 2013: Tinjauan pada Rencana Pelaksanaan Pembelajaran (RPP) Mata Pelajaran Ilmu Pengetahuan Alam. Journal of Natural Science and Integration, ejournal.uin-suska.ac.id, http://ejournal.uinsuska.ac.id/index.php/JNSI/article/view/7110

HIDAYATI, WNUR (2018). PENERAPAN PENDEKATAN SAINTIFIK PADA PEMBELAJARAN IPA KELAS V DI MI ISLAMIYAH KROYA KABUPATEN CILACAP WAHYU NUR HIDAYATI ..., repository.iainpurwokerto.ac.id, http://repository.iainpurwokerto.ac.id/4693/

Irmawati, RD, Supriyati, Y, \& Suseno, M (2018). Pengaruh Strategi Pembelajaran Dan Motivasi Belajar Terhadap Higher Order Thinking Skills (HOTS) Dalam Pembelajaran IPA Siswa Kelas IV Sekolah Dasar. Jurnal Tunas Bangsa, sipeg.unj.ac.id, http://sipeg.unj.ac.id/repository/upload/jurnal/C12715 1.PDF

Ishak, D, Rahmat, A, \& Zubaidi, M (2020). PENGEMBANGAN MODEL PEMBELAJARAN SENTRA BAHAN ALAM MELALUI PENDEKATAN SAINTIFIK PAUD MENARA ILMU DI LIMBOTO. E-PROSIDING ..., ejurnal.pps.ung.ac.id, http://ejurnal.pps.ung.ac.id/index.php/PSI/article/view/361

Jamil, MM (2019). ... ARCS Dalam Pembelajaran Saintifik Untuk Meningkatkan Motivasi Belajar Peserta Didik Pada Peminatan Mata Pelajaran Geografi Di Kelas Matematika Ilmu Alam. IJIS Edu: Indonesian Journal of Integrated ..., journal.iainbengkulu.ac.id, https://journal.iainbengkulu.ac.id/index.php/ijisedu/article/view/1401

Janah, N (2019). KESULITAN GURU DALAM PEMBELAJARAN IPA DENGAN PENDEKATAN SAINTIFIK UNTUK MENCAPAI MEANINGFUL LEARNING. PENSA E-JURNAL: PENDIDIKAN SAINS

Jannah, M (2020). Peningkatkan Hasil Belajar Siswa Dengan Model Pembelajaran Mind Mapping Perspektif Pendekatan Saintifik., repository.iainkudus.ac.id, http://repository.iainkudus.ac.id/4332/

Juwairiah, J (2021). Evaluasi Penggunaan Pendekatan Saintifik di dalam Pembelajaran Siswa Sekolah Dasar. Journal of Integrated Elementary Education, 103.19.37.186, https://103.19.37.186/index.php/jieed/article/view/7717

KHOIRIYAH, SUMI (2020). PENERAPAN PENDEKATAN SAINTIFIK UNTUK MENINGKATKAN KETERAMPILAN PROSES BELAJAR PESERTA DIDIK PADA MATA PELAJARAN IPA DI MIN 1 ..., repo.iain-tulungagung.ac.id, http://repo.iain-tulungagung.ac.id/17826/

Lampiran Permendikbud No. 103 Tahun 2014. Online. https://pgsd.uad.ac.id/wpcontent/uploads/lampiran-permendikbud-no-103-tahun-2014.pdf

MA Insan Generasi Islami. 2019. Cara Melakukan Kegiatan Pembelajaran Berbasis Pendekatan Saintifik. Online. https://maigi.sch.id/cara-melakukan-kegiatanpembelajaran-berbasis-pendekatan-saintifik/ 
Murtiani, M, \& Darvina, Y (2018). ... Perangkat Pembelajaran Elektronik Mata Pelajaran Fisika SMA Berbasis Nilai-nilai Karakter dengan Pendekatan Saintifik sebagai Upaya Implementasi Kurikulum repository.unp.ac.id, http://repository.unp.ac.id/id/eprint/29142

Narut, YF, \& Supardi, K (2019). Literasi sains peserta didik dalam pembelajaran ipa di indonesia. JIPD (Jurnal Inovasi Pendidikan ..., jurnal.unikastpaulus.ac.id, http://jurnal.unikastpaulus.ac.id/index.php/jipd/article/view/214

Ningtyas, RA, \& Purnomo, T (2018). PENERAPAN PENDEKATAN SAINTIFIK PADA MATERI PENCEMARAN LINGKUNGAN DAN DAMPAKNYA UNTUK MENINGKATKAN KETERAMPILAN .... PENSA E-JURNAL: PENDIDIKAN SAINS

Novita, F, Irawati, S, \& Jumiarni, D (2018). Peningkatan aktivitas dan hasil belajar melalui model discovery learning dengan pendekatan saintifik. ... Pendidikan dan Pembelajaran https://ejournal.unib.ac.id/index.php/jppb/article/view/6811 ejournal.unib.ac.id,

Nurdyansyah, N (2018). Model Pembelajaran Berbasis Masalah Pada Pelajaran IPA Materi Komponen Ekosistem. Universitas Muhammadiyah Sidoarjo, eprints.umsida.ac.id, http://eprints.umsida.ac.id/1611

Nurkhasanah, S (2019). Penerapan Model Pembelajaran Inkuiri untuk Meningkatan Aktifitas Belajar Siswa pada Mata Pelajaran Ilmu Pengetahuan Alam Kelas IX. A SMP Negeri 1 Gangga. ... , Pengajaran dan Pembelajaran, e-journal.undikma.ac.id, https://e-journal.undikma.ac.id/index.php/jurnalkependidikan/article/view/1393

Oviana, W (2018). Pengembangan Rencana Pelaksanaan Pembelajaran Berbasis Pendekatan Saintifik Oleh Guru SD dan MI di Kota Sabang. PIONIR: Jurnal Pendidikan

Pinatih, SAC (2021). Pengembangan Media Pembelajaran Komik Digital Berbasis Pendekatan Saintifik pada Muatan IPA Kelas V di SD N 2 Gianyar Tahun Ajaran 2020/2021., repo.undiksha.ac.id, https://repo.undiksha.ac.id/6176/

Pinatih, SAC, \& Putra, DBKNS (2021). Pengembangan Media Komik Digital Berbasis Pendekatan Saintifik pada Muatan IPA Kelas V SD. Jurnal Penelitian dan ..., ejournal.undiksha.ac.id, https://ejournal.undiksha.ac.id/index.php/JJL/article/view/32279

Rachmawati, I (2021). Pengembangan perangkat pembelajaran berbasis pendekatan saintifik dengan model kooperatif jigsaw pada pokok bahasan segiempat untuk siswa kelas 7 SMP. SKRIPSI Mahasiswa UM, mulok.library.um.ac.id, http://mulok.library.um.ac.id/index3.php/74395.html

Ridha, SM (2019). ... PENDEKATAN SAINTIFIK TERHADAP HASIL BELAJAR ISWA KELAS IV PADA MATA PEMBELAJARAN ILMU PENGETAHUAN ALAM TEMA CITA-CITAKU DI .... Pahlawan: Jurnal Pendidikan-Sosial-Budaya, ojs.uvayabjm.ac.id, http://ojs.uvayabjm.ac.id/index.php/pahlawan/article/view/11

Rizki, N, \& Sari, N (2021). Meningkatkan Keterampilan Komunikasi Siswa dengan Menggunakan Pendekatan Saintifik pada Mata Pelajaran Ilmu Pengetahuan Alam di SDN 035 Indrapuri 1A. Jurnal Pendidikan Tambusai, jptam.org, https://www.jptam.org/index.php/jptam/article/view/1083 
Rohmawati, S, Sihkabuden, S, \& ... (2019). Penerapan pendekatan saintifik pada mata pelajaran IPA di MTs Putri Nurul Masyithoh Lumajang. Jurnal Kajian Teknologi ..., journal2.um.ac.id, http://journal2.um.ac.id/index.php/jktp/article/view/4543

Sabiq, AF (2020). Pendekatan Saintifik dalam Pembelajaran Pendidikan Agama Islam., erepository.perpus.iainsalatiga.ac ..., http://e-repository.perpus.iainsalatiga.ac.id/8048/

Sadriani, S, Rede, A, \& Darmadi, IW (2018). Pengaruh Pendekatan Saintifik Terhadap Motivasi Belajar Sains Pada Siswa Kelas IV SD Inpres 1 Sidondo. Jurnal Kreatif Online, http://jurnal.untad.ac.id/jurnal/index.php/JKTO/article/view/4649

jurnal.untad.ac.id,

Saroh, LY, Bektiarso, S, \& Prihandono, T (2019). MODEL KOOPERATIF THINK PAIR SHARE (TPS) DENGAN PENDEKATAN SAINTIFIK PADA PEMBELAJARAN FISIKA. FKIP e-PROCEEDING, jurnal.unej.ac.id, https://jurnal.unej.ac.id/index.php/fkip-epro/article/view/15156

Setiawan, AR (2019). Efektivitas pembelajaran biologi berorientasi literasi saintifik. Thabiea: Journal of Natural Science Teaching, journal.iainkudus.ac.id, http://journal.iainkudus.ac.id/index.php/Thabiea/article/view/5345

Setiawan, AR (2019). Penerapan Pendekatan Saintifik dalam Pembelajaran Biologi sebagai Upaya Melatih Literasi Saintifik. Prosiding Seminar Nasional Biologi, academia.edu, https://www.academia.edu/download/65290840/2020_01_17_1_6_127_1_PB.pdf

Setiawan, AR (2020). Pembelajaran Tematik Berorientasi Literasi Saintifik. Jurnal Basicedu, jbasic.org, http://www.jbasic.org/index.php/basicedu/article/view/298

Setiawan, AR, \& Saputri, WE (2020). Pembelajaran Literasi Saintifik untuk Pendidikan Dasar. Media Penelitian Pendidikan: Jurnal ..., 103.98.176.9, http://103.98.176.9/index.php/mediapenelitianpendidikan/article/view/5794

Sudirman, D, \& Rahmi, EG (2018). Persepsi Guru Bidang Studi Ilmu Pengetahuan Alam Terhadap Pelaksanaan Pendekatan Saintifik dalam Kurikulum 2013 di Smp Negeri 2 Lengayang Kabupaten .... Jurnal Ilmu Pendidikan ..., ojs.stkip-ahlussunnah.ac.id, http://www.ojs.stkip-ahlussunnah.ac.id/index.php/jipa/article/view/57

Sudirman, D, \& Rahmi, EG (2018).... Guru Bidang Studi Ilmu Pengetahuan Alam Terhadap Pelaksanaan Pendekatan Saintifik Dalam Kurikulum 2013 Tingkat Sekolah Menengah Pertama Di $\quad$... $\quad$ SIMBIOSA, journal.unrika.ac.id, https://www.journal.unrika.ac.id/index.php/simbiosajournal/article/download/1490/1 $\underline{114}$

Suryabrata, S. 2013. Metodologi Penelitian. Jakarta: Rajawali Pers

Sutowijoyo, S (2020). Manajemen Pembelajaran Ilmu Pengetahuan Alam Pendekatan Saintifik di Madrasah Tsanawiyah Negeri 2 Kota Kediri., etheses.uin-malang.ac.id, http://etheses.uin-malang.ac.id/25944/

Tirtayani, LA, Wirabrata, DGF, \& Sujana, IW (2019). Pelatihan penyusunan perangkat pembelajaran menggunakan pendekatan saintifik. Widya Laksana, ejournal.undiksha.ac.id, https://ejournal.undiksha.ac.id/index.php/JPKM/article/view/18316

Trisma, E, Hamdi, H, \& Sari, DP (2020). Tingkat Penerapan Pendekatan Saintifik antara Buku Ajar Edupark Fisika Mifan Waterpark Padang Panjang dengan Buku Standar. JURNAL EKSAKTA PENDIDIKAN _.., jep.ppj.unp.ac.id, http://jep.ppj.unp.ac.id/index.php/jep/article/view/424 
Umar, MA (2018). Penerapan Pendekatan Saintifik dengan Metode Pembelajaran Berbasis Proyek (Project-Based Learning) dalam Materi Ekologi. Bionatural: Jurnal Ilmiah Pendidikan Biologi, ejournal.stkipbbm.ac.id, https://www.ejournal.stkipbbm.ac.id/index.php/bio/article/view/194

Utami, PT, Sudiatmika, AR, \& Wiratma, IGL PENGEMBANGAN PERANGKAT PEMBELAJARAN IPBA DENGAN PENDEKATAN SAINTIFIK. ejournal.undiksha.ac.id, https://ejournal.undiksha.ac.id/index.php/JPM/article/viewFile/17525/pdf

Yuliyanto, A, Fadriyah, A, Yeli, KP, \& ... (2018). Pendekatan saintifik untuk mengembangkan karakter disiplin dan tanggung jawab siswa sekolah dasar. Metodik Didaktik: Jurnal https://ejournal.upi.edu/index.php/MetodikDidaktik/article/view/9307

Zahro, R (2020). ... Inferensi Peserta Didik Ditinjau Dari Penerapan Model Pembelajaran Problem Solving Dengan Pendekatan Saintifik Pada Pembelajaran IPA Kelas VII Di SMP Ma'arif ...., etheses.iainponorogo.ac.id, http://etheses.iainponorogo.ac.id/12223/ 